\title{
PEMBINAAN NARAPIDANA DALAM SISTEM PEMASYARAKATAN
}

\author{
Oleh: \\ Ismail Pettanase, SH, MH. \\ (Dosen FH Universitas Muhammadiyah Palembang)
}

\begin{abstract}
ABSTRAK
Pemasyarakatan dinyatakan sebagai suatu sistem pembinaan terhadap para pelanggar hukum dan sebagai suatu pengejawantahan keadilan yang bertujuan untuk mencapai reintegrasi sosial atau pulihnya kesatuan hubungan antara Warga Binaan Pemasyarakatan dengan masyarakat. Pemasyarakatan di Indonesia mengalami perubahan yang cukup berarti, khususnya tentang metode perlakuan terhadap narapidana itu sendiri. Pemikiran mengenai fungsi pemidanaan menurut Indonesia yang menganut ideologi Pancasila tidak lagi sekedar penjeraan tetapi juga merupakan suatu usaha rehabilitasi dan reintegrasi sosial Warga Binaan Pemasyarakatan (WBP) yang telah ditetapkan dengan suatu sistem perlakuan terhadap para pelanggar hukum di Indonesia yang dinamakan dengan sistem pemasyarakatan.
\end{abstract}

Kata Kunci: Pemasyarakatan, Narapidana, Pelanggar Hukum, Masyarakat.

\begin{abstract}
Penitentiary is stated as a system of guidance for lawbreakers and as an embodiment of justice which aims to achieve social reintegration or the restoration of the unity of relations between Prisoners and the community.Penitentiary in Indonesia has experienced significant changes, especially regarding the method of treating prisoners themselves. The idea of the function of punishment according to Indonesia which adheres to the Pancasila ideology is no longer just deterrence but is also an attempt to rehabilitate and reintegrate socially Correctional Guidance (WBP) which has been established with a system of treatment of lawbreakers in Indonesia called the penal system
\end{abstract}

Keywords: Correctional Facilities, Prisoners, Offenders,

\section{A. Latar Belakang}

Adanya model pembinaan bagi narapidana di dalam Lembaga Pemasyarakatan tidak terlepas dari sebuah dinamika, yang bertujuan untuk lebih banyak memberikan bekal bagi Narapidana dalam menyongsong kehidupan setelah selesai menjalani masa hukuman (bebas). Seperti halnya yang terjadi jauh sebelumnya, peristilahan Penjara pun telah mengalami perubahan menjadi pemasyarakatan. Tentang lahirnya istilah Lembaga Pemasyarakatan dipilih sesuai dengan visi dan misi lembaga itu untuk menyiapkan para narapidana kembali ke masyarakat. Istilah ini dicetuskan pertama kali oleh Rahardjo, S.H. yang menjabat Menteri Kehakiman RI saat itu. 
Pemasyarakatan dinyatakan sebagai suatu sistem pembinaan terhadap para pelanggar hukum dan sebagai suatu pengejawantahan keadilan yang bertujuan untuk mencapai reintegrasi sosial atau pulihnya kesatuan hubungan antara Warga Binaan Pemasyarakatan dengan masyarakat.

Pemasyarakatan di Indonesia mengalami perubahan yang cukup berarti, khususnya tentang metode perlakuan terhadap narapidana itu sendiri. Pemikiran mengenai fungsi pemidanaan menurut Indonesia yang menganut ideologi Pancasila tidak lagi sekedar penjeraan tetapi juga merupakan suatu usaha rehabilitasi dan reintegrasi sosial Warga Binaan Pemasyarakatan (WBP) yang telah ditetapkan dengan suatu sistem perlakuan terhadap para pelanggar hukum di Indonesia yang dinamakan dengan sistem pemasyarakatan. Istilah pemasyarakatan untuk pertama kali disampaikan oleh Almarhum Bapak Sahardjo (Menteri Kehakiman pada saat itu) pada tanggal 5 Juli 1963 dalam pidato penganugerahan gelar Doctor Honoris Causa oleh Universitas Indonesia. Pemasyarakatan oleh beliau dinyatakan sebagai tujuan dari pidana penjara. ${ }^{7}$

Plato menyatakan bahwa tidak ada yang bisa mengubah nasib manusia kecuali dirinya sendiri.Dengan adanya suatu perubahan memungkinkan manusia mengenal dirinya sendiri. Proses pengenalan diri sendiri memerlukan tahap motivasi berupa tahap kelanjutan dari introspeksi. Dalam hal pemasyarakatan, Warga Binaan Pemasyarakatan diberikan motivasi untuk dirinya sendiri sehingga dapat memandang positif setiap kejadian. Dengan adanya motivasi diri yang berlangsung terus-menerus, maka akan menimbulkan suatu proses pengembangan diri dengan tahapan self development. ${ }^{8}$

Dengan adanya Undang Undang Pemasyarakatan ini maka makin kokoh usaha-usaha untuk mewujudkan visi sistem pemasyarakatan, sebagai tatanan mengenai arah dan batas serta cara pembinaan Warga Binaan Pemasyarakatan berdasarkan Pancasila yang dilaksanakan secara terpadu antara Pembina, yang dibina dan masyarakat untuk meningkatkan kualitas Warga Binaan Pemasyarakatan agar menyadari kesalahan, memperbaiki diri dan tidak mengulangi tindak pidana sehingga dapat diterima kembali oleh lingkungan masyarakat, dapat aktif berperan dalam pembangunan dan dapat hidup secara wajar sebagai warga yang baik dan bertanggungjawab.

7 Satu tahun kemudian, pada tanggal 27 April 1964 dalam Konferensi Jawatan Kepenjaraan yang dilaksanakan di Lembang Bandung, istilah pemasyarakatan dibakukan sebagai pengganti kepenjaraan. Pemasyarakatan dalam konferensi ini dinyatakan sebagai suatu system pembinaan terhadap para pelanggar hukum dan sebagai suatu pengejawantahan keadilan yang bertujuan untuk mencapai reintegrasi sosial atau pulihnya kesatuan hubungan hidup, kehidupan dan penghidupan Warga Binaan Pemasyarakatan di dalam masyarakat. Dalam perkembangan selanjutnya, pelaksanaan sistem pemasyarakatan semakin mantap dengan diundangkannya Undang Undang Nomor 12 Tahun 1995 tentang Pemasyarakatan.

${ }^{8}$ C.Harsono, Sistem Baru Pembinaan Narapidana, Jakarta: Djambatan, 1995, hal. 10 
Lembaga Permasyarakatan merupakan salah satu komponen dalam Sistem Peradilan Pidana di Indonesia yang bertugas melaksanakan pembinaan terhadap narapidana. Sistem Peradilan Pidana merupakan suatu sistem penegakan hukum sebagai upaya penanggulangan kejahatan. Sistem Peradilan Pidana terdiri dari 4 komponen (sub sistem), yaitu sub sistem kepolisian, sub sistem kejaksaan, sub sistem pengadilan dan sub sistem lembaga pemasyarakatan.

Sistem Peradilan Pidana terbagi manjadi 3 tahap yaitu tahap sebelum sidang pengadilan (pra adjudikasi), tahap sidang pengadilan (adjudikasi), dan tahap setelah pengadilan (post adjudikasi). Dalam mekanisme Sistem Peradilan Pidana mensyaratkan adanya kerjasama antar sub sistem agar Sistem Peradilan Pidana dapat berjalan dengan baik.

Keempat sub sistem dalam Sistem Peradilan Pidana mempunyai tugas yang berbedabeda namun keempat sub sistem tersebut mempunyai tujuan yang sama dan mempunyai hubungan yang sangat erat. Apabila salah satu sub sistem ada yang tidak menjalankan tugas sebagaimana mestinya dapat mempengaruhi sistem secara keseluruhan.

Lembaga Permasyarakatan sebagai sub sistem yang paling akhir yang langsung berhadapan dengan narapidana untuk melaksanakan pembinaan, mempunyai posisi yang strategis dalam mewujudkan tujuan akhir dari Sistem Peradilan Pidana. Lembaga Permasyarakatan diharapkan mampu merealisasikan tujuan akhir Sistem Peradilan Pidana yaitu mencegah timbulnya kejahatan.

Sistem Pemasyarakatan di samping bertujuan untuk mengembalikan Warga Binaan Pemasyarakatan sebagai warga yang baik, juga bertujuan untuk melindungi masyarakat terhadap kemungkinan diulanginya tindak pidana oleh Warga Binaan Pemasyarakatan, serta merupakan penerapan dan bagian yang tidak terpisahkan dari nilai-nilai yang terkandung dalam Pancasila. ${ }^{9}$

Pelaksanakan sistem pemasyarakatan tersebut, diperlukan juga partisipasi atau keikutsertaan masyarakat, baik dengan mengadakan kerjasama dalam pembinaan maupun dengan sikap bersedia menerima kembali Warga Binaan Pemasyarakatan yang telah selesai menjalani pidananya. ${ }^{10}$

Selanjutnya pembinaan diharapkan agar mereka mampu memperbaiki diri dan tidak mengulangi tindak pidana yang pernah dilakukannya. Kegiatan di dalam LP bukan sekedar untuk menghukum atau menjaga narapidana tetapi mencakup proses pembinaan agar warga

\footnotetext{
${ }^{9}$ Adi Sujatno, Sistem Pemasyarakatan Indonesia Membangun Manusia Mandiri. Jakarta: Direktorat Jenderal Pemasyarakatan Departemen Hukum dan HAM RI, 2004, hal. 21.

${ }^{10}$ Ibid. hal. 22-23.
} 
binaan menyadari kesalahan dan memperbaiki diri serta tidak mengulangi tindak pidana yang pernah dilakukan.

Dengan demikian jika warga binaan di LP kelak bebas dari hukuman, mereka dapat diterima kembali oleh masyarakat dan lingkungannya dan dapat hidup secara wajar seperti sediakala. Fungsi Pemidanaan tidak lagi sekedar penjeraan tetapi juga merupakan suatu proses rehabilitasi dan reintegrasi sosial Warga Binaan yang ada di dalam LP.

Tentu saja hal ini sangat kontradiktif apabila dibandingkan dengan visi dan misi pemasyaratan sebagai tempat pembinaan narapidana, agar keberadaannya dapat diterima kembali oleh masyarakat sewaktu bebas. Perlu bagi kita untuk sejenak melihat kembali tujuan pengadaan Lembaga Pemasyarakatan sebagai tempat untuk membina dan menyiapkan seorang narapidana menjadi "lurus" dan siap terjun kembali ke masyarakatnya kelak. Apakah selama ini pola dan cara pembinaan dalam Lembaga Pemasyarakatan sudah sampai pada tujuannya? Apakah bukannya pola pembinaan di LP itu malah membekali si narapidana akan kelak lebih profesional? Butuh pemikiran bersama dalam mengurai benang kusut di balik jeruji besi selama ini.

\section{B. Perumusan Masalah}

Berdasarkan uraian diatas, mengerucut beberapa pertanyaan yang menjadi kerangka pemikiran penulis untuk menyusun makalah ini :

1. Unsur apa saja yang dapat mempengaruhi pembinaan narapidana?

2. Bagaimanakah dukungan terhadap proses pembinaan narapidana dalam pemasyarakatan, apakah sudah sesuai dengan kebutuhan konsep pemasyarakatan itu sendiri?

3. Jika tidak sesuai, apa faktor penghambatnya dan bagaimanakah solusi yang dapat dilakukan?

\section{Pembahasan}

\section{Proses Pembinaan Narapidana dalam Sistem Pemasyarakatan}

Menurut Sahetapy tidak dapat disangkal bahwa dalam pengertian pidana tersimpul unsurunsur penderitaan, tetapi penderitaan dalam tujuan membebaskan bukanlah semata-mata untuk penderitaan agar si pelaku menjadi takut atau merasa menderita akibat suatu pembalasan dendam melainkan derita itu harus dilihat sebagai obat atau sebagai kunci jalan keluar yang membebaskan dan yang memberikan kemungkinan bertobat dengan penuh keyakinan. ${ }^{11}$

\footnotetext{
${ }^{11}$ Ibid, hal. 280.
} 
Peter Hoefnagels mengemukakan tujuan pidana adalah untuk penyelesaian konflik (conflict resolution), mempengaruhi para pelanggar dan orang-orang lain ke arah perbuatan yang kurang lebih sesuai dengan hukum (influencing offenders and possibly other than offenders toward more or less law-conforming behavior). ${ }^{12}$

Rijksen, membedakan antara dasar hukum dari pidana dan tujuan pidana. Dasar hukum dari pidana terletak pada pembalasan terhadap kesalahan yakni dari pembalasan itu terletak pembenaran dari wewenang pemerintah untuk memidana (strafbevoegdheid van de overheid). Apakah penguasa juga akan menggunakan wewenang itu tergantung dari tujuan yang dikehendaki. Tujuan itu merupakan penegakan wibawa, penegakan norma, menakutnakuti, mendamaikan, mempengaruhi tingkah laku dan menyelesaikan konflik. ${ }^{13}$

Selanjutnya Roeslan Saleh berpendapat bahwa pada hakekatnya ada dua poros yang menentukan garis hukum pidana yaitu; pertama dari segi prevensi yaitu bahwa hukum pidana adalah hukum sanksi, suatu upaya untuk dapat mempertahankan kelestarian hidup bersama dengan melakukan pencegahan kejahatan dan kedua dari segi pembalasan yaitu bahwa hukum pidana sekaligus merupakan pula penentuan hukum, merupakan koreksi dari dan reaksi atas sesuatu yang bersifat tidak hukum sehingga dapat dikatakan bahwa pidana adalah selaku merupakan perlindungan terhadap masyarakat dan pembalasan atas perbuatan tidak hukum. ${ }^{14}$

Memahami fungsi Lembaga Pemasyarakatan yang dilontarkan Sahardjo, sejak itu dipakai sistem pemasyarakatan sebagai metode dan pemasyarakatan sebagai proses. Dengan dipakainya sistem pemasyarakatan sebagai metode pembinaan narapidana, jelas terjadi perubahan fungsi Lembaga Pemasyarakatan yang tadinya sebagai tempat pembalasan berganti sebagai tempat pembinaan. Di dalam perjalanannya, bentuk pembinaan yang diterapkan bagi narapidana yang meliputi: ${ }^{15}$

1. Pembinaan berupa interaksi langsung sifatnya kekeluargaan antara pembina dan yang dibina;

2. Pembinaan yang bersifat persuasif, yaitu berusaha merubah tingkah laku melalui keteladanan;

3. Pembinaan berencana, terus-menerus dan sistematis;

${ }^{12}$ Muladi dan Barda Nawawi Arief, Teori-Teori dan Kebijakan Pidana, Bandung: Alumni, 1998, hal. 21.

${ }^{13}$ Ibid, hal 21.

14 Disamping mengandung hal-hal lain yaitu bahwa pidana diharapkan sebagai sesuatu yang akan membawa kerukunan dan pidana adalah suatu proses pendidikan untuk menjadikan orang dapat diterima kembali dalam masyarakat.

${ }^{15}$ Departemen Kehakiman, Pola Pembinaan Narapidana/Tahanan, 1990. 
4. Pembinaan kepribadian yang meliputi kesadaran beragama, berbangsa dan bernegara, intelektual, kecerdasan, kesadaran hukum, keterampilan, mental spiritual.

Keterbatasan sarana dapat merupakan salah satu penghambat pembinaan narapidana seperti yang diharapkan. Oleh karenanya, sulit untuk menghasilkan pembinaan yang efektif, efisien serta berhasil guna. Hal ini cukup beralasan, mengingat tujuan sistem pemasyarakatan itu sangat ideal, sedangkan sarananya sangat terbatas. Akibatnya, setiap petugas akan mengalami kejenuhan mengenai cita-cita pemasyarakatan.

Richard D. Schwartz dan Jerome H. Skolnick, menyatakan sanksi pidana dimaksudkan untuk a) mencegah terjadinya pengulangan tindak pidana (to prevent recidivism); b) mencegah orang lain melakukan perbuatan yang sama similar acts); c) menyediakan saluran untuk mewujudkan motif-motif balas (to provide a channel for the expression of realiatory motives). ${ }^{16}$

Selanjutnya Emile Durkheim mengatakan mengenai fungsi dari pidana adalah untuk menciptakan kemungkinan bagi pelepasan emosi-emosi yang ditimbulkan atau diguncangkan oleh adanya kejahatan (the function of punishment is to create a possibility for the release of emotion that are aroused by the time). ${ }^{17}$

Roger Hood berpendapat bahwa sasaran pidana disamping untuk mencegah terpidana atau pembuat potensial melakukan tindak pidana juga untuk, pertama memperkuat kembali nilai-nilai sosial (reinforcing social values), kedua menentramkan rasa takut masyarakat terhadap kejahatan (allaying public fear of crime). ${ }^{18}$

Ahli di bidang kepenjaraan (penolog) mengakui bahwa ada 3 (tiga) elemen pokok apabila tujuan pemasyarakatan tercapai, yaitu: 1) petugas; 2) narapidana; dan 3) masyarakat. Dipertimbangkannya unsur masyarakat adalah sesuatu yang rasional dan tepat mengingat beberapa hal bahwa narapidana adalah anggota masyarakat yang telah melanggar hukum, serta narapidana juga nantinya setelah lepas menjalani hukuman kembali ke masyarakat.

Sistem pemasyarakatan sebagai petunjuk arah pembinaan narapidana di Lembaga Pemasyarakatan belum mencapai hasil yang memadai, dengan beberapa indikator:

1. Narapidana yang melarikan diri dari Lembaga Pemasyarakatan.

2. Pelanggaran hak-hak narapidana.

3. Penolakan bekas narapidana oleh masyarakat.

4. Keterbatasan sarana maupun prasarana dalam mendukung pembinaan.

\footnotetext{
${ }^{16}$ Op. Cit. Muladi dan Barda Nawawi Arief, hal. 20

${ }^{17}$ Ibid, hal. 19.

${ }^{18}$ Ibid, hal. 21.
} 
Departemen Hukum dan HAM sebagai payung sistem pemasyarakatan Indonesia, menyelenggarakan sistem pemasyarakatan agar narapidana dapat memperbaiki diri dan tidak mengulangi tindak pidana, sehingga narapidana dapat diterima kembali dalam lingkungan masyarakatnya, kembali aktif berperan dalam pembangunan serta hidup secara wajar sebagai seorang warga negara.

Saat seorang narapidana menjalani vonis yang dijatuhkan oleh pengadilan, maka hakhaknya sebagai warga negara akan dibatasi. Sesuai UU No.12 Tahun 1995, narapidana adalah terpidana yang menjalani pidana hilang kemerdekaan di Lembaga Pemasyarakatan. Walaupun terpidana kehilangan kemerdekaannya, tapi ada hak-hak narapidana yang tetap dilindungi dalam sistem pemasyarakatan Indonesia.

Setelah proses pembinaan telah berjalan selama 2/3 masa pidana yang sebenarnya atau sekurang-kurangnya 9 bulan, maka pembinaan dalam tahap ini memasuki pembinaan tahap akhir. Pembinaan tahap akhir yaitu berupa kegiatan perencanaan dan pelaksanaan program integrasi yang dimulai sejak berakhirnya tahap lanjutan sampai dengan selesainya masa pidana. Pada tahap ini, bagi narapidana yang memenuhi syarat diberikan cuti menjelang bebas atau pembebasan bersyarat. Pembinaan dilakukan diluar Lapas oleh Balai Pemasyarakatan (BAPAS) yang kemudian disebut pembimbingan Klien Pemasyarakatan.

\section{Identifikasi Sarana dan Prasarana Pendukung Pembinaan}

Dalam proses pembinaan narapidana oleh Lembaga Pemasyarakatan dibutuhkan sarana dan prasarana pedukung guna mencapai keberhasilan yang ingin dicapai. Sarana dan prasarana tersebut meliputi:

1. Sarana Gedung Pemasyarakatan

Gedung Pemasyarakatan merupakan representasi keadaan penghuni di dalamnya. Keadaan gedung yang layak dapat mendukung proses pembinaan yang sesuai harapan. Di Indonesia sendiri, sebagian besar bangunan Lembaga Pemasyarakatan merupakan warisan kolonial, dengan kondisi infrastruktur yang terkesan "angker" dan keras. Tembok tinggi yang mengelilingi dengan teralis besi menambah kesan seram penghuninya.

2. Pembinaan Narapidana

Bahwa sarana untuk pendidikan keterampilan di Lembaga Pemasyarakatan sangat terbatas, baik dalam jumlahnya maupun dalam jenisnya, dan bahkan ada sarana yang sudah demikian lama sehingga tidak berfungsi lagi, atau kalau toh berfungsi, hasilnya tidak memadai dengan barang-barang yang diproduksikan di luar (hasil produksi perusahan). 
3. Petugas Pembinaan di Lembaga Pemasyarakatan

Berkenaan dengan masalah petugas pembinaan di Lembaga Pemasyarakatan, ternyata dapat dikatakan belum sepenuhnya dapat menunjang tercapainya tujuan dari pembinaan itu sendiri, mengingat sebagian besar dari mereka relatif belum ditunjang oleh bekal kecakapan melakukan pembinaan dengan pendekatan humanis yang dapat menyentuh perasaan para narapidana, dan mampu berdaya cipta dalam melakukan pembinaan.

\section{Paradigma Sistem Pembinaan Narapidana}

Ironis, hampir seluruh tindak kejahatan yang ditangani oleh Sistem Peradilan Pidana Indonesia selalu berakhir di penjara. Padahal penjara bukan solusi terbaik dalam menyelesaikan masalah-masalah kejahatan, khususnya tindak kejahatan di mana "kerusakan" yang ditimbulkan oleh tindak kejahatan tersebut masih bisa di restorasi sehingga kondisi yang telah "rusak" dapat dikembalikan menuju keadaan semula, di mana dalam keadilan restoratif mi dimungkinkan adanya penghilangan stigma dari individu pelaku. Dalam menyikapi tindak kejahatan yang dianggap dapat direstorasi kembali, dikenal suatu paradigma penghukuman yang disebut sebagai restorative justice, di mana pelaku kejahatan didorong untuk memperbaiki kerugian yang telah ditimbulkannya kepada korban, keluarganya dan juga masyarakat. Berkaitan dengan kejahatan yang kerusakannya masih bisa diperbaiki, pada dasarnya masyarakat menginginkan agar bagi pelaku diberikan "pelayanan" yang bersifat rehabilitatif. Masyarakat mengharapkan para pelaku kejahatan akan menjadi lebih baik dibanding sebelum mereka masuk kedalam institusi penjara, inilah yang dimaksud proses rehabilitasi.

Kebutuhan dan keselamatan korban menjadi perhatian yang utama dari proses restorative justice. Korban harus didukung dan dapat dilibatkan secara langsung dalam proses penentuan kebutuhan hasil akhir dari kasus tindak pidana yang dialaminya. Namun dengan demikian bukan berarti kebutuhan pelaku tindak pidana diabaikan. Pelaku tindak pidana harus direhabilitasi dan di-reintegrasikan ke dalam masyarakat. Konsekuensi dari kondisi mi mengakibatkan perlunya dilakukan pertukaran informasi antara korban dan pelaku tindak pidana secara langsung dan terjadinya kesepakatan yang saling menguntungkan di antara keduanya sebagai hasil akhir dari tindak pidana yang terjadi. 


\section{Penutup}

\section{Kesimpulan}

Berdasarkan uraian di atas maka penulis dapat memperoleh kesimpulan sebagai berikut :

Apabila ditinjau melalui tujuan didirikan Lembaga Pemasyarakatan, proses pembinaan yang seharusnya diberikan kepada narapidana belum dapat berjalan. Hal ini disebabkan karena sarana dan prasarana Lembaga Pemasyarakatan yang belum dapat mengakomodir konsep Lembaga Pemasyarakatan sebagai wadah pembinaan narapidana. Selain itu beberapa faktor non-teknis seperti: paradigma tentang narapidana dan wujud pembinaan yang belum sempurna turut memperburuk kondisi pembinaan di pemasyarakatan.

\section{Saran}

Melihat fenomena pemasyarakatan yang ada cukup memprihatinkan, beberapa hal yang ingin penulis sampaikan adalah :

1. Adanya koordinasi terkait antara pihak kepolisian, kejaksaan, pegawai pemasyarakatan, serta masyarakat dalam membina pelaku kejahatan.

2. Pengadaan sarana dan prasarana yang mendukung proses pembinaan narapidana dalam pemasyarakatan, selain itu diperlukan sistem yang berorientasi pada nasib narapidana ketika bebas dan kembali lagi dalam masyarakat.

3. Pemerintah melalui kekuasaannya diharapkan dapat mengubah paradigma tentang pelaku kejahatan.

\section{DAFTAR PUSTAKA}

\section{A. Buku}

C. Harsono, Sistem Baru Pembinaan Narapidana, Jakarta: Djambatan, 1995.

Departemen Kehakiman, Pola Pembinaan Narapidana/Tahanan, 1990.

Hamzah, Andi, Hukum Acara Pidana Indonesia, Jakarta, Sinar Grafika, 2001.

Muladi dan Barda Nawawi Arief, Teori-Teori dan Kebijakan Pidana, Bandung: Alumni, 1998.

Petrus, Irwan Panjaitan, Lembaga Pemasyarakatan dalam Perspektif Sistem Peradilan Pidana, Jakarta, Pustaka Sinar Harapan, 1995.

Sujatno, Adi, Sistem Pemasyarakatan Indonesia Membangun Manusia Mandiri. Jakarta: Direktorat Jenderal Pemasyarakatan Departemen Hukum dan HAM RI, 2004. 


\section{B. Peraturan Perundang-undangan}

UU No 12 Tahun 1995 tentang Pemasyarakatan

PP No 28 Tahun 2006 tentang Perubahan Atas Peraturan Pemerintah Nomor 32 Tahun 1999 Tentang Syarat dan Tata Cara Pelaksanaan Hak Warga Binaan Pemasyarakatan

\section{Internet}

www.media-indonesia.com

www.dephumkam.go.id 